\title{
Synthesis, Characterization and Optimization of PCL - based Nanocapsules for Delivery of Anticancer Chemotheraputic Drug
}

\author{
Omnia Mahareek ${ }^{1 *}$, Abdelgawad Fahmi ${ }^{2}$, Mariam Abdur-Rahman ${ }^{2}$, Mohamed A. \\ Shemis ${ }^{1}$ \\ ${ }^{1}$ Deparrtment of Biochemistry and Molecular biology, Theodor Bilharz Research Institute, \\ Egypt. \\ ${ }^{2}$ Department of Chemistry, Faculty of Science, Cairo University, Egypt.
}

\begin{abstract}
Nanocapsules based drug delivery system has provided an efficient tools in cancer treatment in recent times. The toxicity of anticancer drugs can be decreased through nano-encapsulation using polymeric nanocapsules. This study aimed to synthesis, optimization and characterization of doxorubicin (Dox) loaded biodegradable polycaprolactone (PCL) nanocapsules. Dox loaded PCL nanocapsules were prepared by double emulsion method using dichloromethane as the organic solvent, and polyvinyl alcohol as the external aqueous phase. Formulation parameter such as the effect of weight ratio of drug to polymer was optimized for the synthesis of Dox-PCL nanocapsules. Different weight ratio of Dox loaded PCL nanocapsules (1:20), (1:50) and (3:10) were prepared. Dox-PCL nanocapsules of weight ratio of 3:10 mg had higher DL of $16.88 \%$ than other cases and its average size determined by dynamic light scattering (DLS) was $212 \mathrm{~nm}$. The TEM image revealed that the prepared nanocapsules were spherical in shape in all cases. Also, ZPs were greater in case of Dox-PCL with ratio of $3: 10 \mathrm{mg}$ than other cases, which suggests good stability these synthesized nanocapsules. Finally, these results indicate that the properties such as DL \%, morphology, size and surface charge of the nanocapsules colloidal suspension were better with decreasing the amount of PCL and increasing the amount of Dox.
\end{abstract}

\section{Keywords}

Doxorubicin; Polycaprolactone; Double emulsion; Nanocapsules; Chemotherapeutic drug

*Corresponding author: Omnia Maher Omnia_2516@yahoo.com 
Department of Biochemistry and Molecular biology, Theodor Bilharz Research Institute, Egypt

\section{Introduction}

Globally, Liver cancer is considered as the second cause of death and it has around 850,000 new cases annually (Llovet et al., 2016). In Egypt, Liver cancer constitutes $1.68 \%$ of the total cancer cases and HCC accounts for $70.48 \%$ of all liver tumors among Egyptians (Holah et al, 2015). Patients with cirrhosis exhibit a high probability of developing HCC. Many factors such as infection with the hepatitis B or hepatitis $\mathrm{C}$ viruses, alcoholism, can lead to the development of cirrhosis (Chuang et al., 2009). Examples of chemotherapeutic drugs used to inhibit the progress of advanced liver cancer, HCC are cyclophosphamide, cisplatin, 5fluorouracil and doxorubicin (Wójcik et al., 2015).

Doxorubicin hydrochloride (Dox) $\left(\mathrm{C}_{27} \mathrm{H}_{30} \mathrm{ClNO}_{11}\right)$ is one of the most commonly used chemotherapeutic drugs for HCC treatment since its inception in the 1960 (Mohan and Rapoport, 2010). Mechanism of action of doxorubicin hydrochloride (DOX) is to inhibit the DNA polymerases and topoisomerases and block the cell cycle, resulting in the induction of apoptosis in tumor cells (Tacar et al., 2010). The main obstacle that faces the treatment with Dox is its heavy poisonous side effect on cancer cells as well as normal cells, which reduces its therapeutic effect and use in the clinical practice ( $\mathrm{Hu}$ et al., 2007).The advances in nanotechnology have provided powerful and efficient tools in the development of cancer diagnosis and therapy (Devulapally and Paulmurugan, 2014).

Biodegradable polymeric nanocapsules, which Capable of delivering a wide range of drugs for a sustained period of time into the target sites in a slow release manner, have already shown important improvements in cancer therapy (Chen et al., 2012; Liu Y and Zhang, 2012). Encapsulating Dox into nanoparticles had shown improvements in its biodistribution within the body. Currently, most work involving Dox entrapment into nanocarriers have been performed using polymeric nanocapsules (Fundar et al., 2010). Polycaprolactone (PCL), a biodegradable and biocompatible polymer, which approved by FDA, is useful to encapsulate a wide range of drugs, making it an interesting material for the preparation of carriers with potential applications in therapy (Pohlmann et al., 2013).

The aim of the present study was the synthesis of polymeric nanocapsules with an aqueous inner core enclosed by an organic layer and both are surrounded by an outer aqueous shell which can readily incorporate the anticancer drug Dox into their cores, whereas the 
hydrophilic outer shell can provide stabilization for the nanocapsules. Different weight ratio of Dox-PCL nanocapsules (1:20), (1:50) and (3:10) were prepared by double emulsion technique. Thus, making Dox: PCL nanocapsules with high drug loading for chemotherapeutic applications, to reduce its cytotoxicity against normal cells and increase its therapeutic effect against cancer cells.

\section{Materials and methods}

\section{Material}

Polycaprolactone (Mw. $10000 \mathrm{Da}$ ), polyvinylalcohol (PVA) (Mw: 13,000-23,000 Da), were obtained from (Aldrich, UK). Doxorubicin.HCl solution was purchased from (Ebewe Pharma, Australia). Dichloromethane (DCM) from (Carlo, UK), Polyethylen glycol (PEG) (Mw: 8000 Da) from (Fisher, USA).

\section{Methods}

\section{Preparation of Dox-PCL nanocapsules}

Dox-PCL nanocapsules were produced by modified double emulsion technique $(\mathrm{W} / \mathrm{O} / \mathrm{W})$ with different weight ratio of Dox to PCL of (1:20), (1:50) and (3:10) (Katata et al., 2012). Briefly, Dox. $\mathrm{HCl}$ solution was emulsified with PCL dissolved in $8 \mathrm{ml} \mathrm{DCM}$ using high speed homogenizer (Tekmar, UK) for $3 \mathrm{~min}$ at 5,000 rpm to create the first emulsion phase of water-in-oil (W1/O). Then, the first emulsion is transferred to an aqueous solution containing $35 \mathrm{ml} 2 \%$ PVA and $5 \mathrm{ml} 0.5 \%$ PEG and are homogenized for $5 \mathrm{~min}$ at 8,000 rpm to form the second emulsion phase (W1/O/W2). The resulting mixture was left stirring on magnetic stirrer (C-MAG HS 7, IKA, China) overnight at room temperature, in dark. After evaporation of DCM, the remaining solution was centrifuged using ultracentrifuge (supra25K, Hanil science industrial, Korea) for $1 \mathrm{~h}$ at $13,000 \mathrm{rpm}$ and $10{ }^{\circ} \mathrm{C}$. Finally, the supernatant was transferred to new tube and the pellet was resuspended in $2 \mathrm{ml}$ deionized $\mathrm{H}_{2} \mathrm{O}$ and directly fed into the freeze dryer (Edwards Modulyo, UK) to produce dried powder of Dox- PCL nanocapsules, which was then collected and kept at $4{ }^{\circ} \mathrm{C}$.

\section{Evaluation of Dox encapsulation efficiency and drug loading}

The encapsulation efficiency (EE \%) and drug loading content (DL\%) of Dox-PCL nanocapsules were indirectly quantified using the supernatant after centrifugation of the final nanoemulsion solution at 13,000 rpm for $1 \mathrm{~h}$ by UV-visible spectrophotometer (Model: 
se6100 UV-Vis double beam, Abbota corporation, USA) (Zhang et al., 2015). EE \% and DL $\%$ were measured using the following equation (1) and (2):

$$
\begin{aligned}
& E E(\%)=1-\frac{\text { conc of free Dox }}{\text { conc of total Dox }} \times 100 \\
& D L(\%)=\frac{\mathrm{M} \text { of Dox } \times \mathrm{EE}}{\mathrm{M} \text { of Dox }+\mathrm{M} \text { of Polymer }} \times 100
\end{aligned}
$$

Whereas, M of Dox and M of Polymers are the initial mass of Dox and PCL, respectively, used in the double emulsion technique.

\section{Morphology of Dox-PCL nanocapsules}

The shape of the nanocapsules was determined using transmission electron microscope (TEM) (JEM-1400, Jeol, USA). A small drop of the nanocapsules suspension was added on the carbon coated grid, stained with uranyl acetate and air dried before measurement.

\section{Assessments of nanocapsules size and size distribution}

The average size and PDI of the nanocapsules were measured using DLS (Nanotrac wave II, USA). The sample was diluted and sonicated for $5 \mathrm{~min}$ then measured at room temperature.

\section{Zeta potential analysis of the nanocapsules}

The surface charges of obtained nanocapsules were measured as a function of zeta potential by DLS (Nanotrac wave II, USA).

\section{Results}

\section{Calculation of EE \% and DL \% of Dox-PCL nanocapsules}

Different weight ratio (1:20), (1:50) and (3:10) of Dox-PCL nanocaspsules were successfully prepared by double emulsion technique. Encapsulation efficiency (EE \%) was 69, 71.3 and $73.15 \%$, respectively and drug loading (DL \%) was 3.3, 1.4 and $16.88 \%$, respectively

\section{Morphology of Dox-PCL nanocapsules}

TEM image revealed that Dox-PCL nanocapsules prepared by double emulsion were spherical in shape as shown in figure 1.The nanocapsules appeared as bright spherical entities surrounded by dark stain. It was apparent that Dox was assembled in the nanocapsules core 
surrounded by hydrophobic PCL part and the aqueous phase by PVA was exposed to the outer shell.

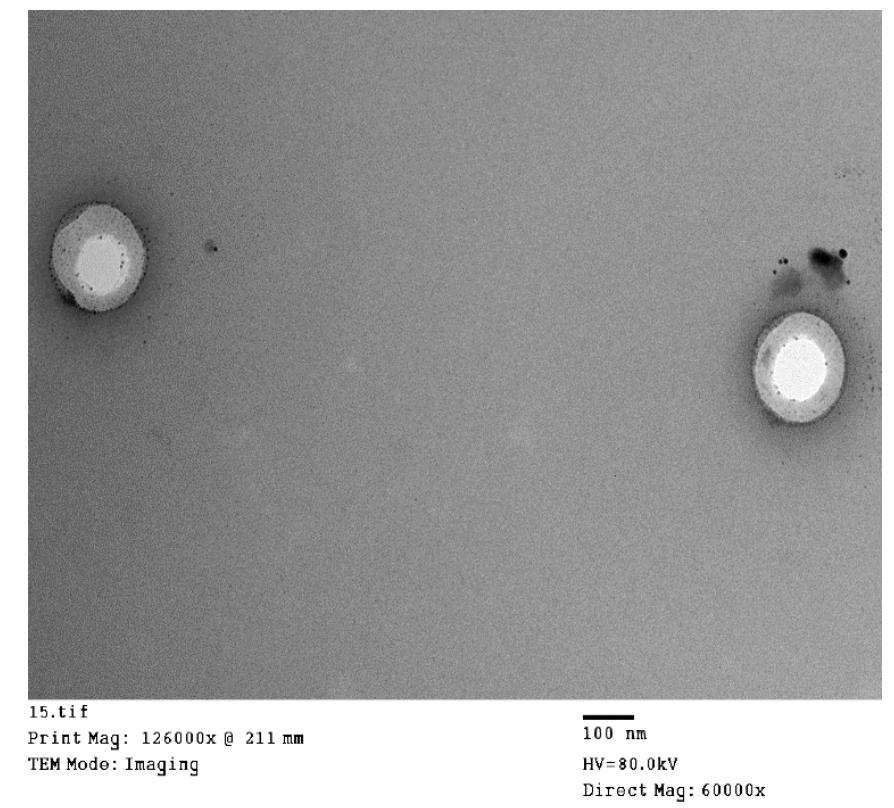

Fig 1: TEM image of Dox-PCL nanocapsules

\section{Assessments of nanocapsules size and size distribution}

The particle size and PDI are illustrated in figure 2 (A, B and C). The average size of the prepared Dox-PCL nanocapsules (1:20), (1:50) and (3:10) determined by DLS were 405, 464, $212 \mathrm{~nm}$ and PDI was $0.26,0.22,0.019$ with a narrow monodispersed unimodal size distribution pattern. 


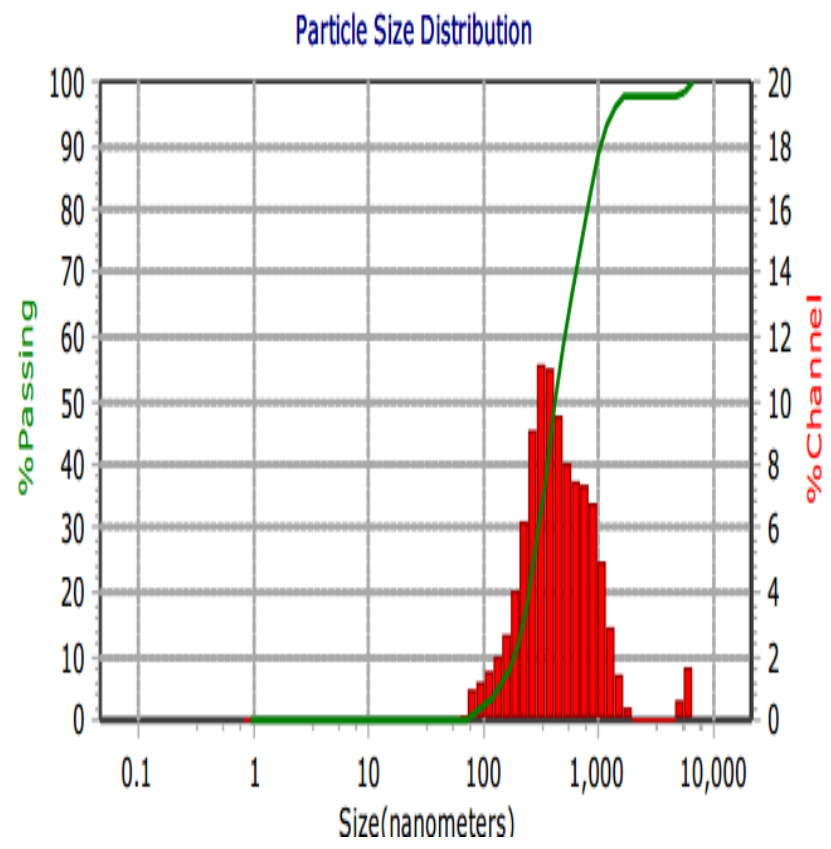

Figure 2A: Particle size distribution of Dox-PCL nanocapsules

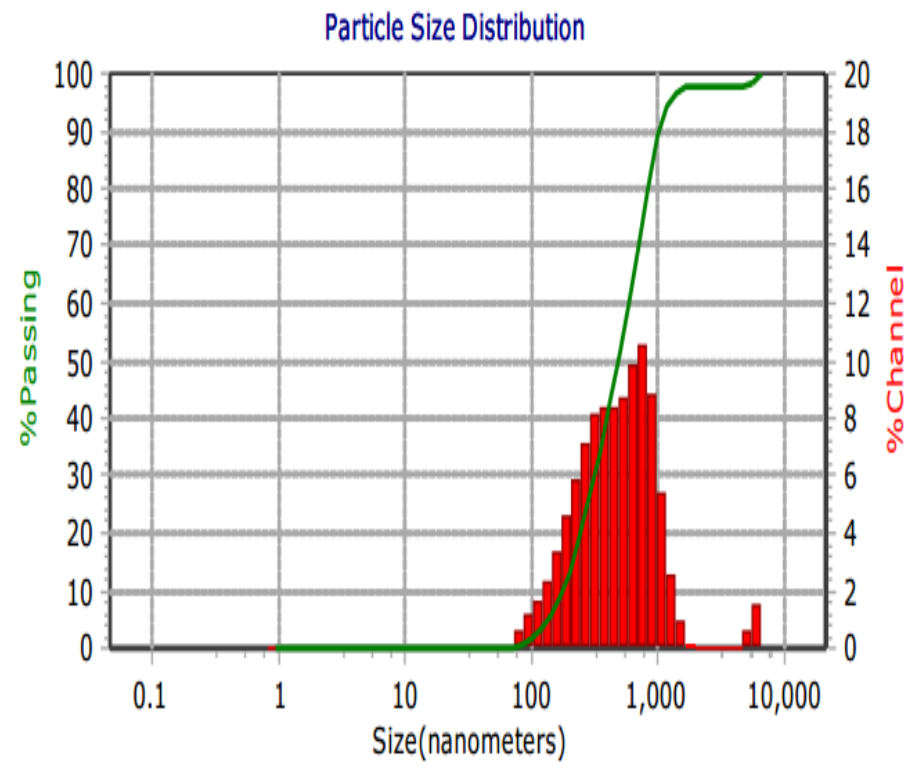

Figure 2B: Particle size distribution of Dox-PCL nanocapsules 


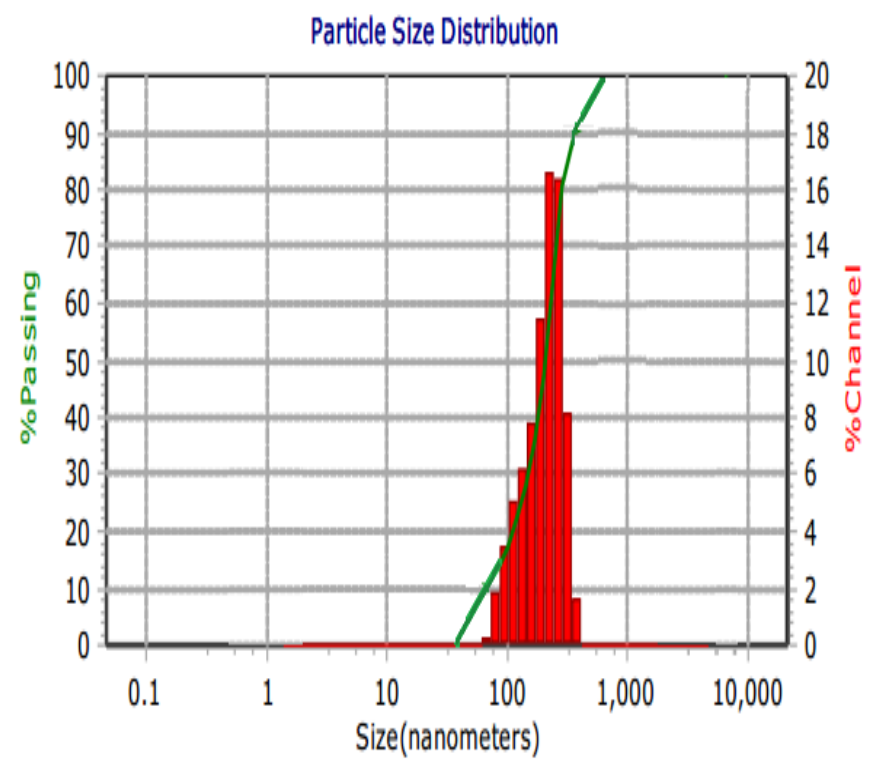

Fig 2C: Particle size distribution of Dox-PCL nanocapsules

\section{Zeta potential analysis of the nanocapsules}

The surface charge of the prepared Dox-PCL nanocapsules (1:20), (1:50) and (3:10) determined by DLS were $-14.1,-18.3$ and -22 .

\section{Discussion}

Polymeric controlled release drug delivery systems (DDS) have considered as an essential field in the development of wide range of chemotherapeutic drugs formulation. Whereas, these polymeric systems able to deliver a wide range of anticancer drugs for a sustained period of time into the target sites in a slow release manner days, weeks, or months, protect them rapid degradation and enhance their bioavailability inside the body (Azizi et al., 2013). In this study, the biocompatible and non-toxic PCL polymeric nanocapsules were successfully loaded with Dox by a modified double emulsion technique (W/O/W) according to (Katata et $a l ., 2012)$ with different weight ratio of Dox-PCL nanocapsules (1:20), (1:50) and (3:10) with drug loading percentage (DL \%) of 3.3, 1.4 and $16.88 \%$, respectively. Thus, nanocapsules prepared with Dox to PCL weight ratio of 3:10 was having the highest drug loading content.

Double emulsion technique is chosen for this study to encapsulate the hydrophilic Dox.HCl into the inner aqueous phase of the core-shell nanocapsules with high drug loading content. The weight ratio of anticancer to polymer were examined to optimize the nanocapsules colloidal suspension parameters such as DL \%, morphology, size and surface charge. For 
intravenous anticancer drug administration, nanomedicines with high drug loading content $>10 \%$ are favorable for cancer therapy, in order to decrease the unwanted drawbacks associated with nanocarrier materials contain low drug content (Shen et al., 2017).

The synthesized Dox-PCL nanocapsules were examined using DLS, and nanocapsules of weight ratio (3:10) was found to have smaller size of $212 \mathrm{~nm}$, PDI of 0.019 with a narrow monodispersed unimodal size distribution pattern and more surface charge of -22.3 mv than other cases. The TEM image revealed that the nanocapsules were spherical in shape as shown in figure 1. Previous studies had shown that the spherical shape of nanocapsules has a vital role in the distribution of the anticancer drug, especially in biological practices, including internalization, passage through the blood circulation system and directing to the sites of cancer (Gratton et al., 2008). Transference of spherical nanocapsules is predictable to be much easier because of their distinct symmetry, whereas non-spherical nanocapsules may align or flip in the company of flow (Moghimi et al., 2001).

The size of nanocapsules used in drug delivery systems should be range from 10 to $250 \mathrm{~nm}$. Thus, this size is large enough to protect them from rapid leakage into blood capillaries but small enough to run away from fixed macrophages that found in the Reticular Endothelial System (RES), such as the spleen and liver (Gref et al., 2000). Additionally, zeta potential (ZP) is considered as an important parameter to expect the storage stability of the colloidal suspension of the nanocapsules. The high values of $\mathrm{ZP}$, either positive or negative are needed to approve stability and evade aggregation of the nanocapsules by electrostatic repulsive forces (Dash et al., 2012). ZP of more than $\pm 13 \mathrm{mV}$ indicates stable nanoparticles (He et al., 2015). PDI is considered as a numerical value representing the homogeneity of the sample.

Poly diversity index (PDI) is as a numerical value representative for the homogeneity of the nanocapsules colloidal suspension sample. If PDI value is less than 0.4 , the particles of the sample are having similar size. In case, the value of PDI is more than 0.4 , the sample is having similarity in size. If PDI is greater than 1 , then the nanocapsules sample is considered completely heterogeneous (Tshweu et al., 2013).

\section{Conclusion}

In conclusion, hydrophilic Dox.HCl were successfully loaded into PCL polymeric nanocapsules with different weight ratio by modified double emulsion technique. High drug loading content $(16.18 \%)$ were obtained by increasing the amount of Dox and decreasing the 
amount of PCL. The synthesized nanocapsules were spherical in shape with high zeta potential value, which considered as an indicator of stable colloidal suspension of Dox-PCL nanocapsules. Finally, Dox-PCL nanocapsules with ratio of $(3: 10)$ could offer a successful and promising potential application by minimizing healthy tissues exposure, while increasing Dox therapeutic effects.

\section{Acknowledgments}

This work was funded by the Egyptian Ministry of scientific research - STDF project (Grant No. 17-2-120).

\section{References}

Azizi M, Farahmandghavi F, Joghataei M, Zandi M, Imani M, Bakhtiary M, Farid Dorkoosh F and Ghazizadeh F. Fabrication of protein-loaded PLGA nanoparticles: effect of selected formulation variables on particle size and release profile. J Polym Res, 2013, 20:110- 124.

Chen K J, Tang L, Garcia M A, Wang H, Lu H, Lin WY, Hou S, Yin Q, Shen C K and Cheng J. The therapeutic efficacy of camptothecin-encapsulated supramolecular nanoparticles. Biomaterials, 2012, 33:1162-1169.

Chuang S C, La Vecchia C and Boffetta P. Liver cancer: descriptive epidemiologyand risk factors other than HBV and HCV infection. Cancer letters, 2009.

Dash T K and Konkimalla V B. Poly-e-caprolactone based formulations for drug delivery and tissue engineering: a review. Control release, 2012, 158(1):15-33.

Devulapally R and Paulmurugan R. Polymer nanoparticles for drug and small silencing RNA delivery to treat cancers of different phenotype. Wiley Interdiscip Rev Nanomed Nanobiotechnol, 2014.

Fundar A, Cavalli R, Bargoni A, Vighetto D, Zara G P and Gasco M R. Non-stealth and stealth solid lipid nanoparticles (SLN) carrying doxorubicin. Pharmacol Res, 2010, 42:337343.

Gratton S, Ropp P, and Pohlhaus P. The effect of particle design on cellular internalization pathways", Proceedings of National Academy of science, 2008, 105(33):11613-11618. 
Gref R, Lueck M, Quellec P, Marchand M, Dellacherie E, Harnisch S, Blunk T, and Mu“ller R H. Stealth' corona-core nanoparticles surface modified by polyethylene glycol (PEG): influences of the corona (PEG chain length and surface density) and of the core composition on phagocytic uptake and plasma protein adsorption", Colloids and surface B: biointerfaces, 2000, 18(3-4):301-313.

He X, Li L and Su H. Poly (ethylene glycol)-blockpoly (epsilon-caprolactone)-and phospholipid-based stealth nanoparticles with enhanced therapeutic efficacy on murine breast cancer by improved intracellular drug delivery. Nanomedicine, 2015, 10:1791-1804.

Holah N S, El-Azab D S, H A and Sweed D M. Hepatocellular carcinoma in Egypt: epidemiological and histopathological properties. enoufia Medical, 2015, 28(3):718-724.

$\mathrm{Hu} \mathrm{T}$, Le Q, Wu Z and $\mathrm{Wu} \mathrm{W}$. Determination of doxorubicin in rabbit ocular tissues and pharmacokinetics after intravitreal injection of a single dose of doxorubicin-loaded poly- $\beta$ hydroxybutyrate microspheres. J Pharm Biomed Anal, 2007, 43:263-269.

Katata L, Tshweu L, Naidoo S, Kalombo L and Swai H. Design and formulation of nanosized spray dried Efavirenz-Part I: influence of formulation parameters. Nano Res, 2012.

Liu Y and Zhang N. Gadolinium loaded nanoparticles in theranostic magnetic resonance imaging. Biomaterials, 2012, 33:5363-5375.

Llovet J M., Zucman-Rossi j, Pikarsky E, Sangro B, Schwartz M, Sherman M and Gores G. Hepatocellular carcinoma", Nature reviews-Disease primers, 2016.

Moghimi S M, Hunter A C and Murray J C. Long-circulating and targetspecific nanoparticles: theory to practice. Pharmacological reviews, 2001, 53(2): 283-318.

Mohan P and Rapoport N. Doxorubicin as a molecular nanotheranostic agent: effect of doxorubicin encapsulation in micelles or nanoemulsions on the ultrasound-mediated intracellular delivery and nuclear trafficking. Mol Pharmaceutics, 2010, 7(6):1959-1973.

Pohlmann A R, Fonseca F N, Detoni K C, Coradini K, Beck R C and Guterres S S. Poly(ecaprolactone microcapsules and nanocapsules in drug delivery. Expert opin drug deliv, 2013.

Shen S, Wu Y, Liu Y, and Wu D. High drug-loading nanomedicines: progress, current status, and prospects. Nanomedicine, 2017, 12:4085-4109. 
Tacar O, Sriamornsak P and Dass CR. Doxorubicin:An update on anticancermolecular action, toxicity and novel drug delivery systems. J Pharm Pharmacol, 2013, 65(2):157-170.

Tshweu L, Katata L, Kalombo L, and Swai H. Nanoencapsulation of water-soluble drug, lamivudine, using a double emulsion spray-drying technique for improving HIV treatment. Nano Res, 2013.

Wójcik M, Lewandowski W, Król M, Pawłowski K, Mieczkowski J, Lechowski R, Zabielska K. Enhancing Anti-Tumor Efficacy of Doxorubicin by Non-Covalent Conjugation to Gold Nanoparticles In Vitro Studies on Feline Fibrosarcoma Cell Lines. Plos one, 2015.

Zhang T, Wang H, Ye Y, Zhang X, and Wu B. Micellar emulsions composed of mPeg$\mathrm{Pcl} / \mathrm{McT}$ as novel nanocarriers for systemic delivery of genistein: a comparative study with micelles. Nanomedicine, 2015, 10:6175-6184. 
الملخص باللغة العربية

تصنيع وتوصيف وتحسين خصائص كابسولات النانونية المصنعه من بوليمر البي سي ال من اجل توصيل مضادات السرطانات

أمنيه ماهر "'، عبد الجواد فهمي"، مريم عبد الرحمن و محمد أ. شميس' ' قسم الكيمياء الحيويه و البيولوجيا الجزيئيه، معهز تيودور بلهارس للأبحاث، مصر. r قسم الكيمياء، كليه العلوم، جامعه القاهره ، مصر.

قدم نظام توصيل الأدوية القائم على كبسو لات النانو فاعليه في علاج السرطان في الآونة الأخيرة. يمكن تقليل سمية عقار العيدروكلوريد دوكسوروبيسين (Dox) من خلال استخدام الكبسولات النانوية البوليمرية. حيث تهدف هذه الدراسة إلى تخليق ، تحسين وتوصيف عقار الدوكسوروبيسين (Dox) المحمل في الكابسولات النانونية البوليميرية القابلة للتحلل (PCL). تم تحضير الكابسولات النانونية البوليميرية باستخدام طريقة الاستحلاب المزدوج (Double Emulsion) باستخدام الدي كلورو ميثان كمذيب عضوي وكحول بولي فينيل كمرحلة مائية خارجية ، وتم تجميع البوليمرات ذاتيا الى دقائق نانوية

بشكل شبيه بتركيب Shell/Core.

تم در اسه تأثير نسبة الوزن من العقار الي البوليمر وذلك من اجل تحسين خصائص الكابسو لات النانونية البوليميريه ، فقد تم إعداد نسبة وزن مختلفة من العقار (Dox) الي البوليمر (PCL) وهي (I: (ب)؛

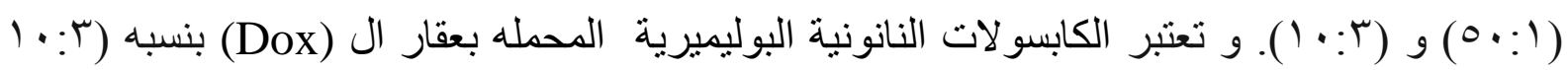

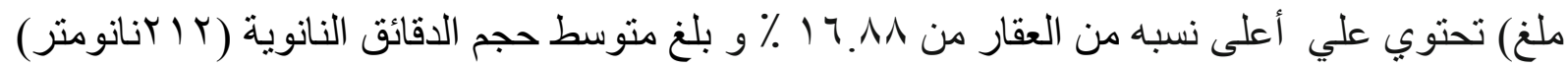
الذي تم تحدديه بو اسطة تقنية ( DLS) وكانت قيمة (0.019) مع نمط توزيع أحادي. كثفت صورة المجهر الالكتروني النافذ (TEM) أن الدقائق النانوية المعّدة بطريقة الاستحلاب المزدوج كانت كروية

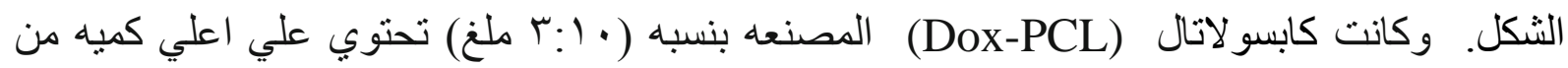
الثحنات، مما يشير إلى ثبات جيد لهذه الكبسولات النانوية. و أخيرًا ، تشير هذه النتائج إلى أن المعلمات مثل نسبه تحميل العقار بداخل الكابسولات، الثكل ، الحجم وشحنة السطح الكابسولات النانونية البوليميريه كانت أفضل مع تقليل كمية البوليمير (PCL) و زياده كميه العقار (Dox). 